\title{
A RASTER-BASED STORMWATER SIMULATION MODEL AND ITS APPLICATION IN INUNDATION MITIGATION PLANNING
}

\author{
Chau Nguyen Xuan QUANG ${ }^{1}$ and Minjiao LU2,3 \\ 1 Student Member of JSCE, Graduate Student, Dept. of Civil and Environmental Engineering, Nagaoka University of \\ Technology (1603-1 Kamitomioka, Nagaoka, Niigata 940-2188, Japan) \\ ${ }^{2}$ Member of JSCE, Dr. of Eng., Professor, Dept. of Civil and Environmental Engineering, Nagaoka University of \\ Technology (1603-1 Kamitomioka, Nagaoka, Niigata 940-2188, Japan) \\ ${ }^{3}$ Member of JSCE, Dr. of Eng., Adjunct Professor, School of River and Ocean Engineering, Chongqing Jiaotong \\ University (Chongqing, China)
}

\begin{abstract}
A raster-based stormwater simulation model is formulated and applied in this study. The proposed model employs the raster-based distributed approach for describing the surface rainfall runoff process. Surface runoff is generated from each grid cell and then is routed to the inlets/manholes of drainage channel network by using 2-D diffusion wave. The hydraulic process in the drainage channel network is performed by using the EXTRAN module, a component of the Storm Water Management Model (SWMM). The input flow rate at inlets is calculated by using weir equation. The surcharge outflow rate from the drainage channels is calculated by using Preissman slot concept. The proposed model is successfully applied to reproduce the heavy flood event on August 4, 1998 in Kamedagou basin, Niigata Prefecture, Japan. Further more, the well-calibrated stormwater simulation model is utilized to inundation mitigation planning in the study area.
\end{abstract}

Key Words: Overland flow, EXTRAN model, urban inundation, raster-based stormwater modeling

\section{INTRODUCTION}

Storm Water Management Model (SWMM) (Huber and Dickinson, 1988) is a comprehensive and widely accepted model for stormwater simulation. Practical applications indicated that the EXTRAN (EXtended TRANsport) module (the hydraulic component of SWMM) is powerful for hydraulic simulation of drainage channel network. However, the RUNOFF module (the hydrologic component of SWMM) is insufficiently powerful to describe the spatial variability of surface rainfall runoff process.

Surface runoff simulation in the RUNOFF module is based on the semi-distributed approach. Runoff is produced at individual subcatchment and then routes to its outlet by using non-linear reservoir concept. This method could lead to several limitations. Firstly, it is difficult to separate subcatchment due to its boundary is not usually clear, especially in flat areas. Secondly, the spatial variability of hydrologic parameters could not be handled in detail like the raster-based distributed approach as presented in the previous researches (Smith, M. B, 1993, Pierre Y. J et al., 1995). Further more, the semi-distributed approach is difficult to express the flow rate and water depth at desired points in the watershed interior.

In this study, a raster-based stormwater simulation model is formulated in order to overcome above inconveniences. The raster-based distributed approach is applied for describing the surface rainfall runoff process. Runoff is generated from each individual grid cell and then is routed to the inlets of drainage channel network by using 2-D diffusion wave. The runoff that drains into the inlets is expressed as weir equation. The EXTRAN module is used for simulating the flow process in the drainage channel network. Surcharge outflow is contributed against the ground surface when the flow discharge in the channel exceeds the design capacity. The surcharge outflow rate is determined from the EXTRAN module by using Preissman slot concept. This surcharge flow is given as source point for overland flow routing in next time step.

The proposed model is applied to reproduce the 
heavy flood event on August 4, 1998 in very flat and low-land area, Kamedagou basin, Niigata Prefecture, Japan. Next, the well-calibrated stormwater simulation model is utilized to determine the needed capacity of pumping and drainage network in order to reduce inundation in this basin.

\section{RASTER-BASED STORMWATER SIMULATION MODEL}

Raster-based stormwater simulation model has four main portions: Surface runoff generation, overland flow routing, channel flow routing, and linkage of surface flow and channel flow. Detailed description of these portions is as follow.

\section{a. Surface runoff generation}

In raster-based runoff simulation approach, the basin is sub-divided into square grid cells at a given resolution as demonstrated in Fig.1. Each grid cell contains the information on surface elevation, roughness coefficient, infiltration parameters, percentage of impervious area, and depression storage depth.

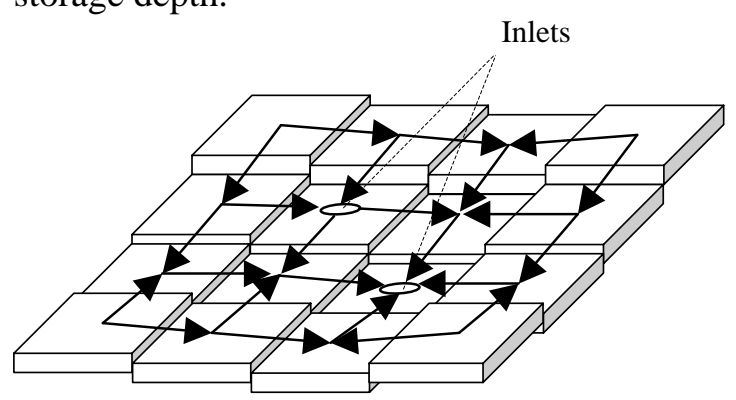

Fig.1 Raster-based runoff generation demonstration

Surface runoff is generated from each individual grid cell. For each grid cell, the land surface is divided into percentage of pervious and impervious area. The runoff is estimated for pervious and impervious part respectively. It is assumed that no runoff drains from pervious area to impervious area and vice versa. In the impervious area, the runoff equals to the rainfall intensity. In the pervious area, the runoff equals to rainfall intensity after subtracting infiltration loss. The surface runoff of each grid cell equals to total runoff generating from pervious part and impervious part.

Rainfall intensity is interpolated into each grid cell using the inverse distance method. The interpolation equation is:

$$
i(j, k)=\frac{\sum_{n=1}^{n n g} \frac{i_{n}\left(j_{r g}, k_{r g}\right)}{d_{m}^{2}}}{\sum_{n=1}^{n n g} \frac{1}{d_{m}^{2}}}
$$

where $i(j, k)$ is the rainfall intensity at cell $(j, k)$ $(\mathrm{mm} / \mathrm{hr}), \mathrm{i}_{\mathrm{n}}\left(\mathrm{j}_{\mathrm{rg}}, \mathrm{k}_{\mathrm{rg}}\right)$ is the rainfall intensity at cell( $\mathrm{j}_{\mathrm{rg}}$, $\mathrm{k}_{\mathrm{rg}}$ ) that raingauge located $(\mathrm{mm} / \mathrm{hr}), \mathrm{d}_{\mathrm{m}}$ is the distance from cell $(\mathrm{j}, \mathrm{k})$ to $\mathrm{n}^{\text {th }}$ raingauge located at cell $\left(\mathrm{j}_{\mathrm{rg}}, \mathrm{k}_{\mathrm{rg}}\right)(\mathrm{m})$, $\mathrm{nrg}$ is total number of rain gauges.

The Green-Ampt model is used to estimate infiltration rate in pervious area. The basic equation is:

$$
\mathrm{f}=\mathrm{K}_{\mathrm{s}}\left(1+\frac{\mathrm{S}_{\mathrm{u}} \mathrm{IMD}}{\mathrm{F}}\right)
$$

where $\mathrm{f}$ is the infiltration rate $(\mathrm{m} / \mathrm{s}), \mathrm{F}$ is the cumulative infiltration depth (m), $S_{u}$ is the average capillary suction at the wetting front (m), IMD is the initial moisture deficit $(\mathrm{m} / \mathrm{m}), \mathrm{K}_{\mathrm{s}}$ is the saturated hydraulic conductivity (m/s).

\section{b. Overland flow routing}

Overland flow occurs when the water depth in the grid cell exceeds the depression storage depth as illustrated in Fig.2.

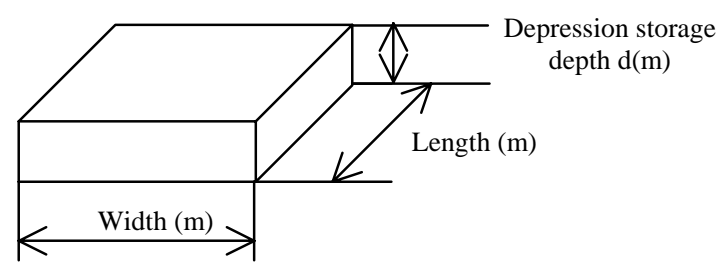

Fig.2 Illustration of depression storage depth in each grid cell

Lal Wasantha A. M. (1998) has analyzed and shown that the 2-D diffusion wave is adequate for overland flow modeling. The diffusion wave is capable of modeling backwater effect like the dynamic wave but it is simpler than the dynamic wave. The accuracy of these two models is not quite different. In addition, excluding the inertia terms from the dynamic wave can help to increase the numerical stability because the water depth of overland flow is very small. Therefore, in this study, the 2-D diffusion wave is selected to model overland flow.

The governing equations of 2-D diffusion wave include the continuity equation

$$
\frac{\partial \mathrm{h}}{\partial \mathrm{t}}+\frac{\partial \mathrm{q}_{\mathrm{x}}}{\partial \mathrm{x}}+\frac{\partial \mathrm{q}_{\mathrm{y}}}{\partial \mathrm{y}}=\mathrm{q}
$$

and the moment equations for $\mathrm{x}$ and $\mathrm{y}$ direction

$$
\begin{aligned}
& \mathrm{S}_{\mathrm{fx}}=\mathrm{S}_{0 \mathrm{x}}-\frac{\partial \mathrm{h}}{\partial \mathrm{x}} \\
& \mathrm{S}_{\mathrm{fy}}=\mathrm{S}_{0 \mathrm{y}}-\frac{\partial \mathrm{h}}{\partial \mathrm{y}}
\end{aligned}
$$

where $h$ is surface water depth (m), $q_{x}$ is unit flow rate in the $\mathrm{x}$-direction $\left(\mathrm{m}^{3} / \mathrm{s} / \mathrm{m}\right), \mathrm{q}_{\mathrm{y}}$ is unit flow rate in the y-direction $\left(\mathrm{m}^{3} / \mathrm{s} / \mathrm{m}\right)$, q is external flow $\left(\mathrm{m}^{3} / \mathrm{s}\right)$, $\mathrm{S}_{0 \mathrm{x}, \mathrm{y}}$ is bed slope in the $\mathrm{x}$ - and $\mathrm{y}$-direction, respectively, $\mathrm{S}_{\mathrm{f} x \mathrm{y}}$ is friction slope in the $\mathrm{x}$ - and 
y-direction, respectively.

The equations of 2D-diffusion wave are solved by using the explicit finite difference scheme. The boundary cells block the inflow across to the simulated watershed. Thus, the flow depth and discharge of these cells are taken as zero. The initial discharge $Q_{0}(j, k)$ at time $t=0$ set to zero. The initial water depth $h_{0}(j, k)$ equals to the water depth of cell $(\mathrm{j}, \mathrm{k})$ at time $\mathrm{t}=0$.

\section{c. Channel flow routing}

EXTRAN (EXtended TRANsport) module is a component of SWMM. In this study, it is employed for hydraulic simulation in the drainage channel network. In EXTRAN module, a link-node concept is used for representation of drainage network. The conceptual overview of this approach is shown as Fig.3. The conduit network is idealized as series of links which are connected at nodes. Inflows (inlet hydrographs) and outflows (surcharges) of EXTRAN module are taken place at nodes.

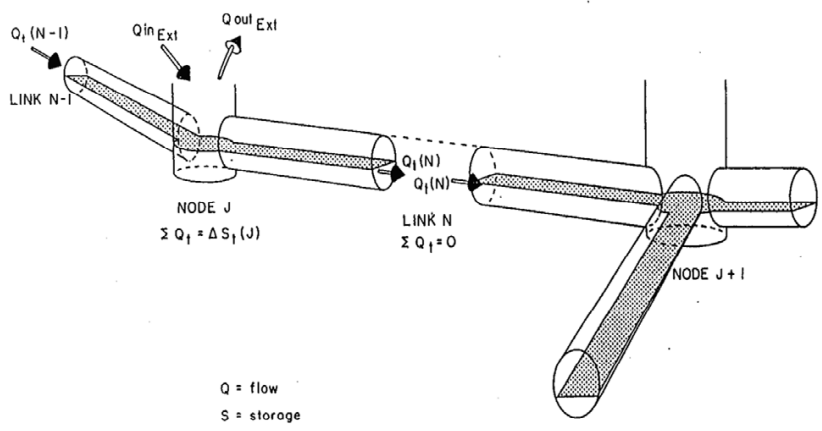

Fig.3 Conceptual representation of the EXTRAN module

EXTRAN module can perform flow routing both branched and looped network of open and/or closed channel. It has capacity of simulating the following elements: pipes, manholes, weirs, orifices, pumps, storage basins, and outfall structures. Further more, this model can simulate backwater effect, reverse flow in the drainage channel because the flow routing is performed by the dynamic wave. The governing equations are:

$$
\begin{aligned}
& \frac{\partial \mathrm{A}}{\partial \mathrm{t}}+\frac{\partial \mathrm{Q}}{\partial \mathrm{x}}=0 \\
& \frac{\partial \mathrm{Q}}{\partial \mathrm{t}}+\frac{\partial\left(\mathrm{Q}^{2} / \mathrm{A}\right)}{\partial \mathrm{x}}+\mathrm{gA} \frac{\partial \mathrm{H}}{\partial \mathrm{x}}+\mathrm{gAS}_{\mathrm{f}}=0
\end{aligned}
$$

where A is the cross sectional area $\left(\mathrm{m}^{2}\right), \mathrm{Q}$ is the discharge $\left(\mathrm{m}^{3} / \mathrm{s}\right)$, $g$ is the gravitational acceleration $\left(\mathrm{m} / \mathrm{s}^{2}\right), \mathrm{H}$ is the hydraulic head $(\mathrm{m})$, and $\mathrm{S}_{\mathrm{f}}$ is the friction slope.

An explicit finite different method is used to solve these equations. Detailed numerical schemes could be found in the model's manual (Huber and Dickinson, 1988).

\section{d. Linkage of surface flow and channel flow}

The surface flow and channel flow is exchanged through the inlets of the drainage channel network. The surface runoff drains into the storm sewer network though the inlets as shown in Fig.4a. The drainage channel network transports these flows to the basin outlet. During transportation process, if the actual discharge exceeds the design discharge of conduit, the flow surcharges through inlets onto ground surface as shown in Fig.4b.

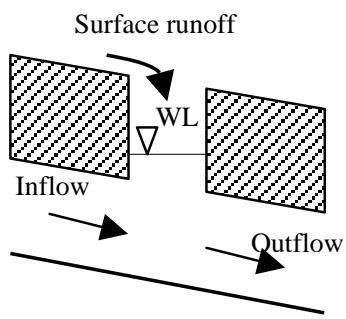

(a)

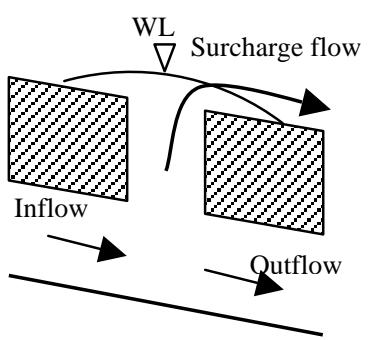

(b)
Fig.4a, b Description of inflow and outflow at nodes

It is assumed that the surface runoff only flows into the inlet if surcharge did not occur at this inlet in previous computation time-step. If the inlet was surcharged in last time-step, the inflow set to zero. The inflow discharge contribute to inlet is calculated by using the weir equation as Eq.(8).

The weir equation is:

$$
\mathrm{Q}_{\text {inlet }}=\mathrm{k}_{\mathrm{w}} \mathrm{L}_{\mathrm{w}} \sqrt{2 \mathrm{~g}} \mathrm{~d}^{1.5}
$$

where $k_{w}$ is weir discharge coefficient, $L_{w}$ is weir length $(\mathrm{m}), \mathrm{g}=9.81\left(\mathrm{~m} / \mathrm{s}^{2}\right)$ is acceleration of gravity, $\mathrm{d}$ is flow depth (m).

The surcharge outflow from node is determined from EXTRAN module by using Preissman slot concept. Detailed description of this computation is presented in the model's manual (Huber and Dickinson, 1988).

\section{MODEL APPLICATION}

\section{a. Study area}

The study area, Kamedagou basin, is located in Niigata Prefecture, the northern part of the Chubu region, Japan (Fig.5). Its drainage area is approximately $100 \mathrm{~km}^{2}$. The basin is flat and low land area. It is closely bounded by the Shinano River in the west, the Koagano River in the south, and Agano River in the east. The northern side of this basin is Japan Sea. This basin is partly urbanized area. Landuse of the basin is classified 
into: highly urbanized, low urbanized, cultivated, paddy field, water surface (Fig.5).

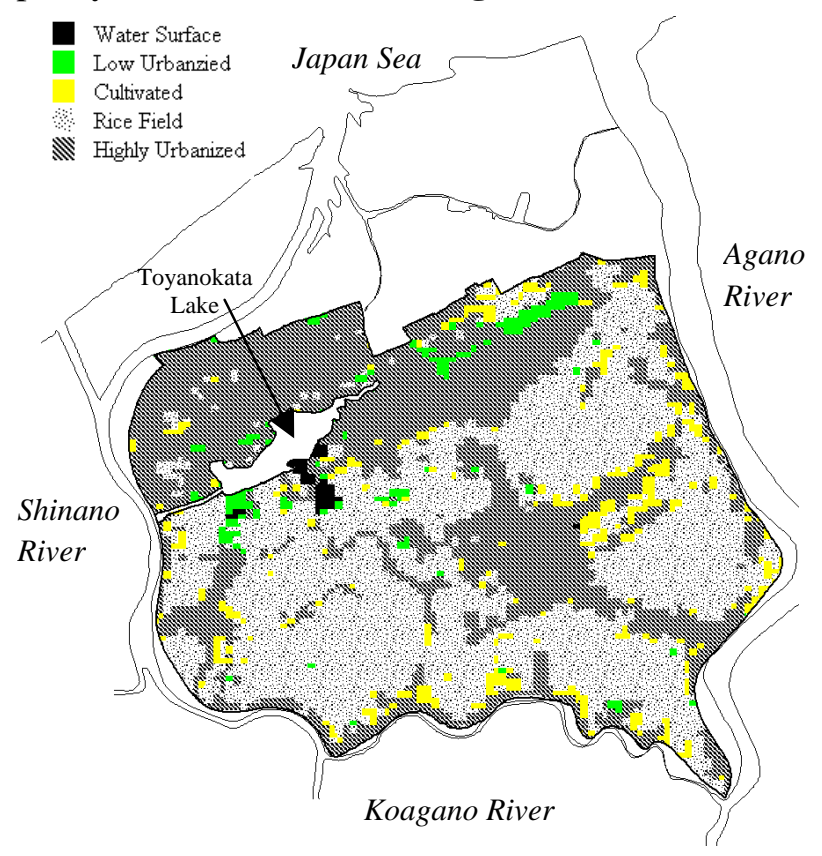

Fig.5 Kamedagou Basin and its landuse

Runoff of the basin results from excess rainfall; there are no inflows from neighbor basins. Drainage in this basin is executed by pumping because the mean elevation of the basin is lower than the water level of the surrounding rivers. The runoff is collected by the drainage channel network as illustrated in Fig.6. Part of the runoff is directly pumped out by Chubu, Kuraoka, Manjo, and Nihongi pumping stations. The remainder runoff concentrates into Toyanokata Lake and is pumped out by Oyamatsu pumping station. Location of these pumping stations is shown as Fig.6.

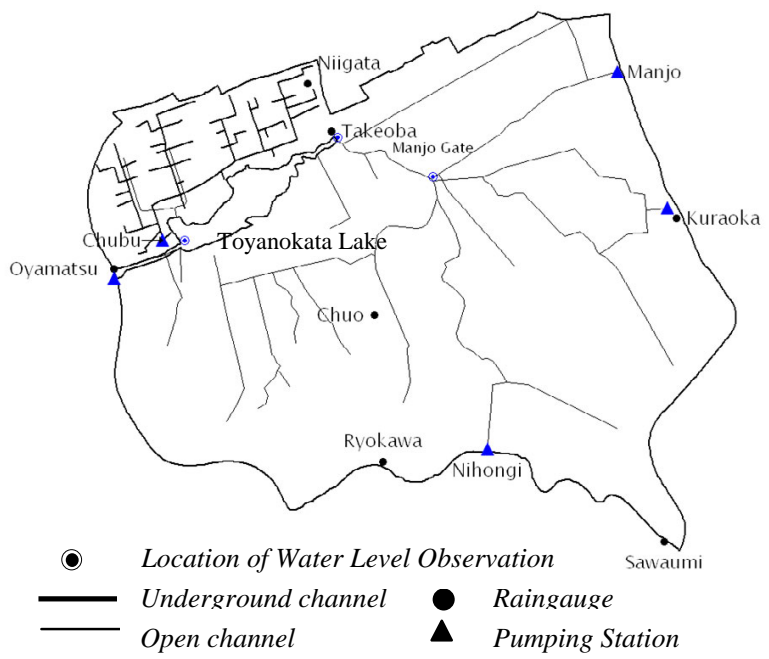

Fig.6 Drainage channel network, study raingauge, pumping station location

\section{b. Data preparation and model setup}

Inputs for the raster-based stormwater simulation model consist of the data for simulating of surface runoff and drainage channel flow. Required input for surface runoff simulation includes surface elevation, roughness coefficient, rainfall intensity, percentage of impervious area, and infiltration parameters. These data are prepared in the raster format with $50 \mathrm{~m}$ resolution. The surface elevation is derived from laser scanner data after filtering the non-ground points such as roofs, car, and high obstacles, etc. Because of the limitation of number of pages, the methodology for filtering the laser scanner data is presented in other report. The roughness coefficient value is estimated by using landuse map. Because the simulated flood event occurred in the wet period, the percentage of impervious area and the soil parameters are not necessary. The rainfall intensity of seven rain gauges (namely Niigata, Chubu, Chuo, Takeoba, Ryokawa, Sawaumi, and Kuraoka) (Fig.6) located inside the basin is interpolated into each grid cell using inverse distance method as Eq.(1). Required input data for simulating the drainage network include the information on channel cross section, bed elevation, length, and channel location.

The relationship between water level and storage volume of Toyanokata Lake as shown in Fig.7 is used for simulating this lake in EXTRAN module. The observed discharge time-series of five pumping stations as shown in Fig.8 is used for simulating these pumping stations.

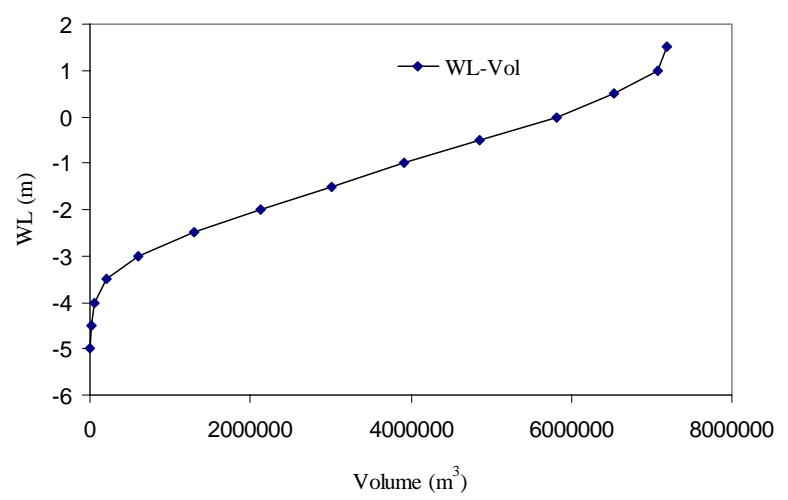

Fig.7 Relationship between water level and storage volume of Toyanokata Lake

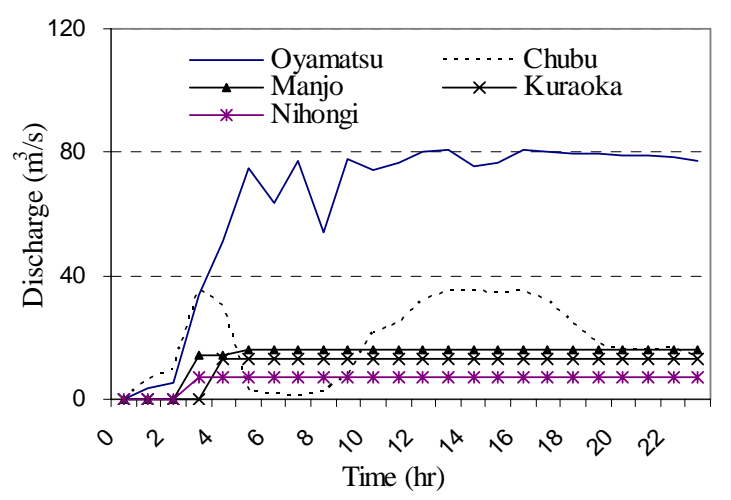

Fig.8 Observed pumping discharge 


\section{c. Calibration of the parameters}

The aim of calibrating the raster-based stormwater simulation model is to adjust the computation time-step, the initial conditions, the roughness coefficient of channel flow and overland flow. Because the 2D diffusion-wave equations are solved by using explicit scheme, it requires relative small time-step for stability. The time-step finalized after trial and error is one second. The initial water level in Toyanokata Lake is $-2.52 \mathrm{~m}$. This value equals to the observed water level before rainfall event. The initial water level in paddy field equals to $0.01 \mathrm{~m}$ and equals to zero for other landuse types. The roughness coefficient value is not fixed for each landuse type. The roughness coefficient varies from 0.01 to 0.07 for highly urbanized, from 0.1 to 0.2 for low urbanized, from 0.1 to 0.3 for cultivated area, and from 0.25 to 0.45 for paddy field. The roughness coefficient of open channel and closed pipe are 0.012 and 0.014 , respectively. The storage value of paddy field is $0.05 \mathrm{~m}$.

\section{d. Simulation results}

The simulated water level results are compared with the observed water level at Takeoba, Toyanokata Lake and Manjo Gate as shown in Fig. 9, 10, 11.

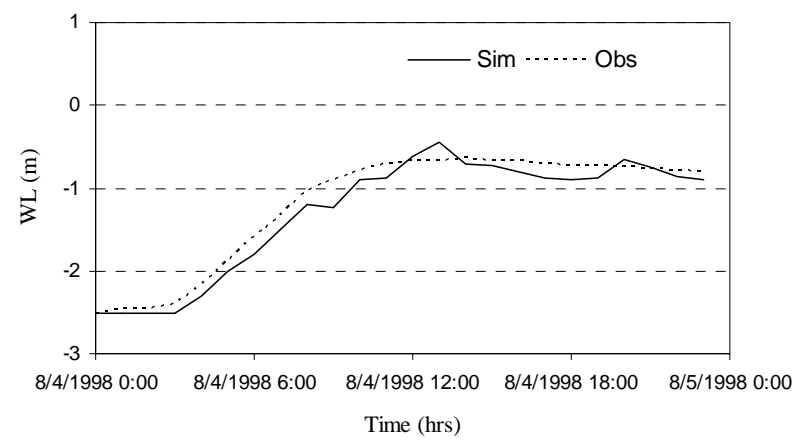

Fig.9 Simulated and observed water level at Toyanokata Lake

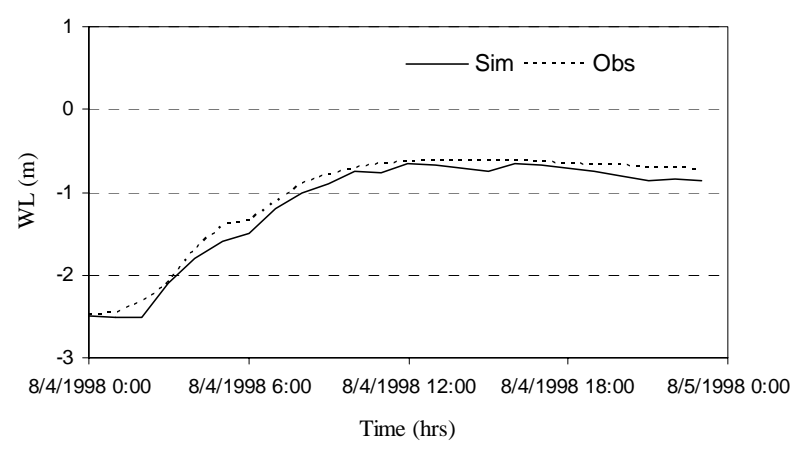

Fig.10 Simulated and observed water level at Takeoba

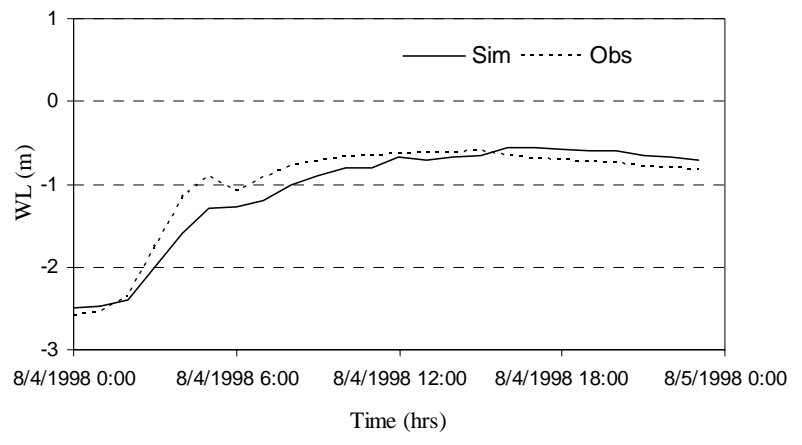

Fig.11 Simulated and observed water level at Manjo Gate

Fig.12 shows the simulated inflow discharge flow into Toyanokata Lake. It can be seen from Fig.12 that the concentration time of runoff is about two hours and the peak discharge is about $300 \mathrm{~m}^{3} / \mathrm{s}$.

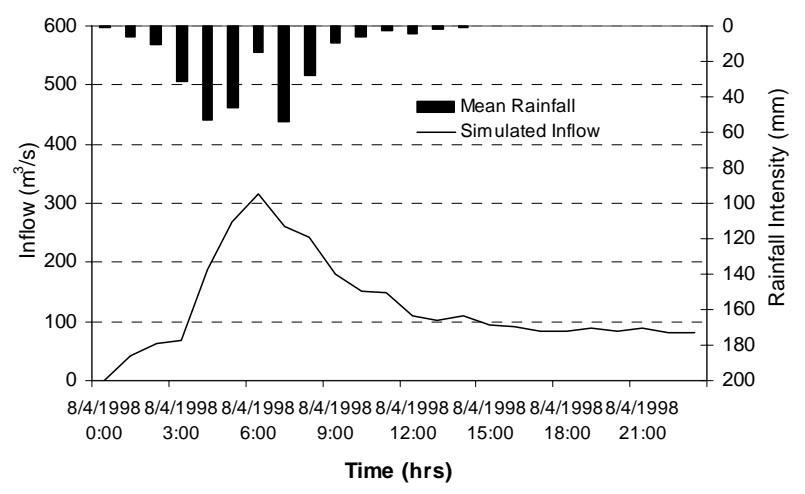

Fig.12 Inflow of Toyanokata Lake

Fig.13 shows the maximum simulated water depth of the flood event on August, 04, 1998. The areas have the maximum water depth above $0.1 \mathrm{~m}$ is considered as inundated areas. The observed inundated area is bounded by the dashed line. The result indicates that simulated inundation extent quite matches with the observed one

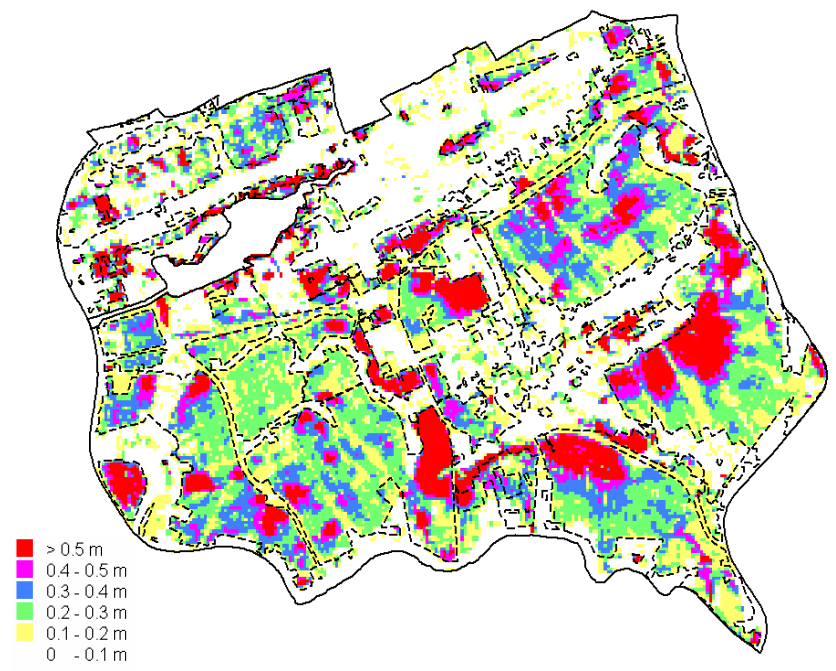

Fig.13 Maximum simulated water depth of the flood event on August, 04, 1998 


\section{e. Inundation mitigation planning}

The well-calibrated stormwater simulation model is applied to inundation mitigation planning in Kamedagou basin. Inundation in this basin is mainly caused by insufficient capacity of pumping rate and drainage channel flow. First of all, the additional pumping rate is determined by adding more pumping rate and evaluates its effect on inundated areas. The Oyamatsu pumping station is selected for adding more pumping rate because it connects to Toyanokata Lake which receives most of excess rainfall in this basin. Next, it checks on the simulated inundation map if there are several local inundated areas even the high pumping rate was added. It means that more construction of drainage channel is necessary for such areas.

The simulation water level varies according to additional pumping rate is shown as Fig.14. It can be seen from Fig.14 that when the additional pumping rate is $40 \mathrm{~m}^{3} / \mathrm{s}$, the water level in Toyanokata Lake is decrease about $1 \mathrm{~m}$. In the case of additional pumping rate raised up to $60 \mathrm{~m}^{3} / \mathrm{s}$, the water level is only decrease about $0.5 \mathrm{~m}$ and it is lower than the ground elevation of the basin. Therefore, it can be concluded that the additional pumping rate from 40 to $50 \mathrm{~m}^{3} / \mathrm{s}$ is necessary to mitigate inundation in Kamedagou basin. However, inundation is also caused by insufficient conveyance capacity of drainage channel. The visualization of water depth over the basin is useful for detecting such areas. Fig.15 shows the maximum simulated water depth inside the basin when adding more pumping rate of $50 \mathrm{~m}^{3} / \mathrm{s}$. In this case, the water level in Toyanokata Lake is lower than the ground elevation inside the basin but the highly urbanized areas located in the northern side of Toyanokata Lake is still suffered from inundation. It means that the underground channel network in this area is insufficient to transfer the runoff. Therefore, it is necessary to construct more drainage channel in this area.

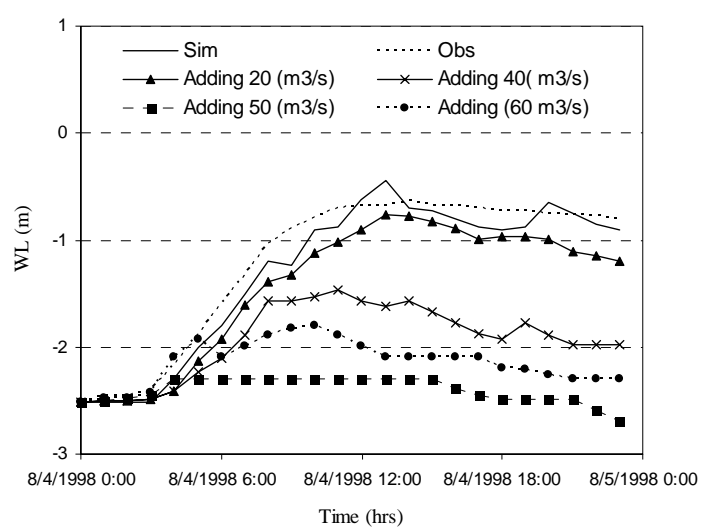

Fig.14 Water level in Toyanoka Lake with different pumping rate

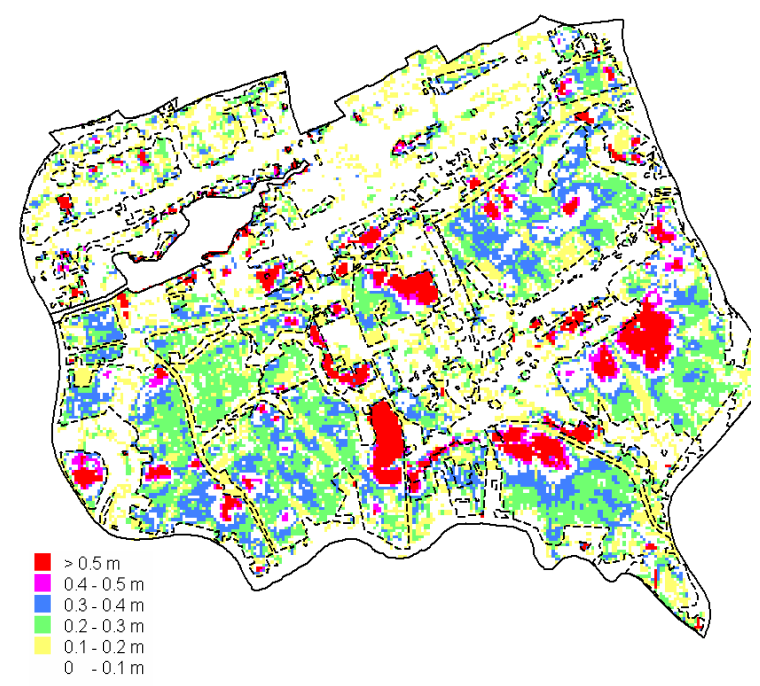

Fig.15 Maximum simulated water depth in case of adding more pumping capacity of $50 \mathrm{~m}^{3} / \mathrm{s}$ at Oyamatsu pumping station

\section{CONCLUSIONS}

In this study, a raster-based stormwater simulation model is successfully proposed and applied to inundation mitigation planning. This model has capacity of handling the spatial variability of hydrologic parameters in detail. In addition, it is powerful to simulate the drainage network system. The simulated results indicated that more construction of drainage channel in highly urbanized area located in the northern side of Toyanoka Lake is needed for avoiding inundation. The needed pumping capacity suggests for removing inundated areas is about 40 to $50 \mathrm{~m}^{3} / \mathrm{s}$.

ACKNOWLEDGMENT: The authors wish to thank for the digital data given by Niigata City Government.

\section{REFERENCES}

1) Huber, W. and Dickinson, R.: Storm water management model, Version 4, User's Manual. Report No.EPA/600/3-88/001a, US Environmental Protection Agency, Athens, Georgia, USA, 1988.

2) Lal Wasantha, A. M.: Performance comparison of overland flow algorithms, Journal of Hydraulic Engineering, ASCE, Vol.124 (4), pp.342-349, 1999.

3) Pierre, Y. J., Bahram, S. and Fred, L. O.: Raster-based hydrologic modeling of spatially-varied surface runoff, Water Resources Bulletin, American Water Resource Association, pp.523-536, 1995.

4) Smith, M. B.: A Grid-based distributed parameter hydrologic model for urban areas, Hydrological Process, Vol.7, pp. 45-61, 1993.

(Received September 30, 2007) 